Leibniz-Institut für

Wirtschaftsforschung

Halle

Bank Risk Proxies and the Crisis of 2007/09: A Comparison

Felix Noth

Lena Tonzer

September 2015

No. 13

IWH-DISKUSSIONSPAPIERE

IWH DISCUSSION PAPERS 
Authors: Felix Noth

Halle Institute for Economic Research (IWH)

Department of Financial Markets

E-mail: Felix.Noth@iwh-halle.de

Phone: +49 3457753702

Otto-von-Guericke University Magdeburg

E-mail: felix.noth@ovgu.de

\section{Lena Tonzer}

Halle Institute for Economic Research (IWH)

Department of Financial Markets

E-mail: Lena.Tonzer@iwh-halle.de

Phone: +49 3457753835

The responsibility for discussion papers lies solely with the individual authors. The views expressed herein do not necessarily represent those of the IWH. The papers represent preliminary work and are circulated to encourage discussion with the authors. Citation of the discussion papers should account for their provisional character; a revised version may be available directly from the authors.

Comments and suggestions on the methods and results presented are welcome.

IWH Discussion Papers are indexed in RePEc-EconPapers and in ECONIS.

Editor:

\section{Halle Institute for Economic Research (IWH) - Member of the Leibniz Association}

Address: $\quad$ Kleine Maerkerstrasse 8, D-06108 Halle (Saale), Germany

Postal Address: P.O. Box 1103 61, D-06017 Halle (Saale), Germany

Phone: $\quad+49345775360$

Fax: $\quad+493457753820$

Internet: $\quad$ www.iwh-halle.de

ISSN $1860-5303$ (Print)

ISSN 2194-2188 (Online) 


\title{
Bank Risk Proxies and the Crisis of 2007/09: A Comparison*
}

\begin{abstract}
Motivated by the variety of bank risk proxies, our analysis reveals that nonperforming assets are a well-suited complement to the Z-score in studies of bank risk.
\end{abstract}

Keywords: banking, financial institutions, risk proxies

JEL Classification: G21, G28, G32

* All errors are our own. 



\section{Introduction}

The financial crisis of 2007/09 has anew brought the issue of bank risk at the heart of the academic discussion. A review of the literature shows that different proxies that come from balance sheet and profit and loss information of banks are used to measure bank risk. However, there is no consensus which measure fits best to gauge bank risk. This becomes crucial, if the measures capture different aspects of bank risk, which then leads to different interpretations of results conditional on the risk proxy. We aim to provide an overview by comparing the most commonly used measures for bank risk for the population of U.S. commercial banks between 1995 and 2013.

We employ four risk proxies. First, we use the Z-score which indicates banks' distance to default by calculating the difference between banks' profitability and the equity ratio of banks, scaled by the volatility of bank profitability (Laeven and Levine, 2009, Berger et al., 2009, Anginer et al., 2013, 2014, Klomp, 2014, Gropp et al. 2014). Second, non-performing assets which include loans past due 30 or 90 days, nonaccrual loans and other real estate owned indicating bank asset risk are used by, e.g., Barth et al. (2004), Berger et al. (2009), Gropp et al. (2010), Cole and White (2012) or Jiménez et al. (2013) 1 Third, loan loss provisions are an estimate of future losses that reduce the operating income for the current period (Ahmed et al., 1999, Cebenoyan and Strahan, 2004, Laeven and Majnoni, 2003). Fourth, loan loss reserves (allowances) are a contra asset that reflect the amount of loan provisions on banks' balance sheets and reduce the book value of loans (Elliott et al., 1991, Hasan and Wall, 2004, Ng and Roychowdhury, 2014).

According to Carbo et al. (2009) who investigate various proxies for bank competition, we do three things in this study. First, we use data for U.S. commercial banks between 1995 and 2013 and calculate four common proxies for bank risk (Section 2). In Section 3, we then analyse correlations and explanatory power between these variables and test whether the measures are useful in predicting bank failures Cole and White, 2012; Dam and Koetter, 2012; Lepetit and Strobel, 2015, Ng and Roychowdhury, 2014; Shaffer, 2012a b, Wheelock and Wilson, 2000). We give a short conclusion in Section 4

\section{Data}

We use balance sheet and profit and loss data for all U.S. commercial banks between q4:1992 and q4:2013 provided by the Federal Deposit Insurance Corporation (FDIC). We append information on bank failures for the same period from the FDIC Failed Bank List. The FDIC provides quarterly data. We require for the banks to have consecutive quarters only which results in a maximum number of 10,332 banks in 1995 decreasing to 6,055 banks in 2013. We exploit the quarterly observations and calculate a 12-quarter rolling standard deviation $(S D(\mathrm{RoA}))$ of banks' return on assets (RoA) $)^{2}$ for each bank $i$

\footnotetext{
${ }^{1}$ Some only use non-performing loans.

${ }^{2}$ FDIC item roa.
} 
which limits the observation period to 1995-2013. We then collapse the data on a bank-year $(i, t)$ level. We calculate a Z-score for each bank and year with

$$
\mathrm{Z}_{- \text {score }_{i t}}=\frac{\mathrm{EQ}_{i t}+\mathrm{RoA}_{i t}}{S D(\mathrm{RoA})_{i t}}
$$

EQ is the ratio of bank equity over total assets $3^{3}$ The Z-score indicates a bank's loss absorbing capacity (Laeven and Levine, 2009), i.e., if the Z-score is lower, the bank is less stable. Z-scores are often skewed, therefore it is common to take the natural logarithm (Laeven and Levine, 2009) which we also do (hereafter Z-score). Also Lepetit and Strobel (2015) show that the log of the Z-score performs well to capture insolvency risk. We multiply the Z-score by -1 so that more negative values indicate more stable banks.

Next, we calculate the ratio of non-performing assets (NPA) $4^{4}$ over total asset: 5 according to Cole and White (2012) which includes loans past due 30 and 90 days, nonaccrual loans and other real estate owned. We further calculate banks' loan loss reserves ${ }^{6}$ over total assets (LLR) which reflects banks' contra asset items that reduce the loan volume from the balance sheet. The equivalent item from the profit and loss statement is loan loss provision $7^{7}$ which should reflect a reasonable estimate of coming losses from loans 8 We again standardize by total assets (LLP). Figure 1 provides mean values for NPA, LLR, LLP and the Z-score over time. All four risk proxies indicate an increase in risks during the recent crisis.

Figure 1: Risk proxies for U.S. banks over time

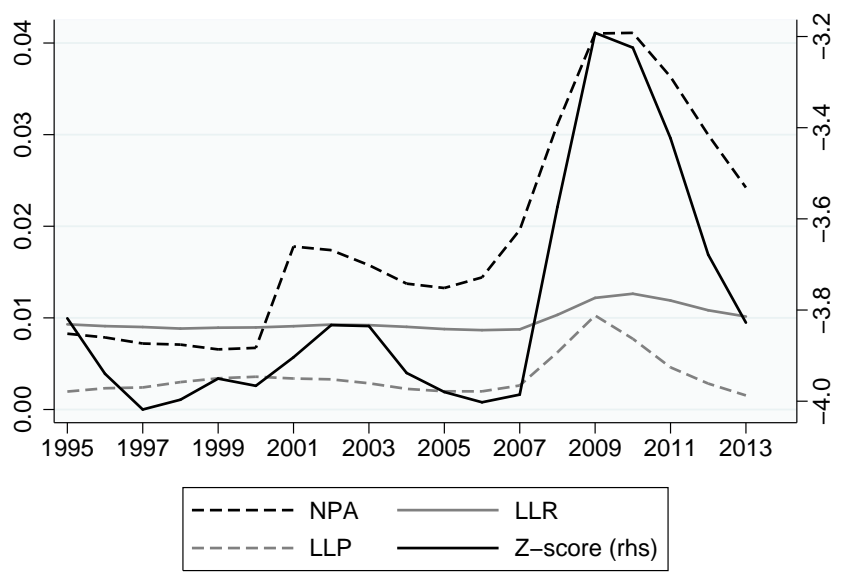

${ }^{3}$ FDIC item eqv.

${ }^{4}$ FDIC items: p3asset, p9asset, naasset and ore.

${ }^{5}$ FDIC item asset.

${ }^{6}$ Allowances is equivalent. The FDIC item lnatres.

${ }^{7}$ FDIC item elnatr.

${ }^{8}$ We winsorize one massive outlier value $(-12018)$ to the next value of the distribution. 


\section{Results}

Table 1 shows correlations between all four risk proxies for the period 1995-2013. Banks' Z-score, NPA and LLR are reasonably and significantly correlated whereas the correlation of NPA with the other two variables is highest ${ }^{9}$ In each case, movements in one variable are mirrored less than $50 \%$ in the other variables. Correlations with LLP are very weak and not significant which might indicate that loan loss provisions do not capture asset bank risk adequately.

\begin{tabular}{lrrrr}
\multicolumn{1}{c}{ Table 1: Correlations } & & & \\
\hline & Z-score & NPA & LLR \\
\hline NPA & 0.4341 & & & \\
& & $(0.0000)$ & & \\
LLR & 0.3194 & 0.4864 & \\
& $(0.0000)$ & $(0.0000)$ & 0.000 & 0.0036 \\
LLP & -0.0060 & 0.0018 & $(0.035)$ \\
& & $0.0233)$ & $(0.4935)$ & $(0.1614)$ \\
\hline
\end{tabular}

Correlation coefficients with p-values in parentheses.

Figure 2 shows R-squared values from regressions in which we explain one risk proxy $k=1, \ldots, 4$ with the remaining $j$ proxies.

$$
R i s k_{k i t}=\boldsymbol{x}_{j \neq k, i t}^{\prime} \boldsymbol{\beta}+\epsilon_{i t}
$$

Figure 2(a) thereby considers the full sample period while Figure 2(b) provides results from regressions based on cross sections for each year between 1995 and 2013. For the full period, we find that 13.36\% of the variation of banks' Z-score is explained by NPA, LLR and LLP. Contrary, the variation in NPA explained by Z-score, LLR and LLP is the highest among the four proxies showing a value of $28.21 \%$. This indicates that NPA contains relevant information as concerns the other three variables. Figure 2(b) shows that the variation in LLR and LLP explained by the other risk proxies is sensible to crisis periods. Comparing the pattern over time for the explained variation in the Z-score and NPA, we find again a higher R-squared for NPA.

The ultimate signal for bank risk is a default of a financial institution. We use a probability model explaining the occurrence of a bank failure (0/1) with the four risk proxies (lagged by one year).

$$
\operatorname{Pr}(\text { Failure }=1)=F\left(\boldsymbol{x}_{i t-1}^{\prime} \boldsymbol{\beta}\right)
$$

Table 2 shows marginal effects for probit regressions of Equation (3). We find that lagged Z-scores and NPAs explain bank failures by roughly 40\%. In line with previous results, NPA shows the highest explanatory power. In comparison, LLP and LLR only explain roughly $12 \%$ and $16 \%$ of the variation in

9 Hasan and Wall (2004) also find that NPA is a good proxy for LLR. 
Figure 2: Variation explained among risk proxies (R-squared)

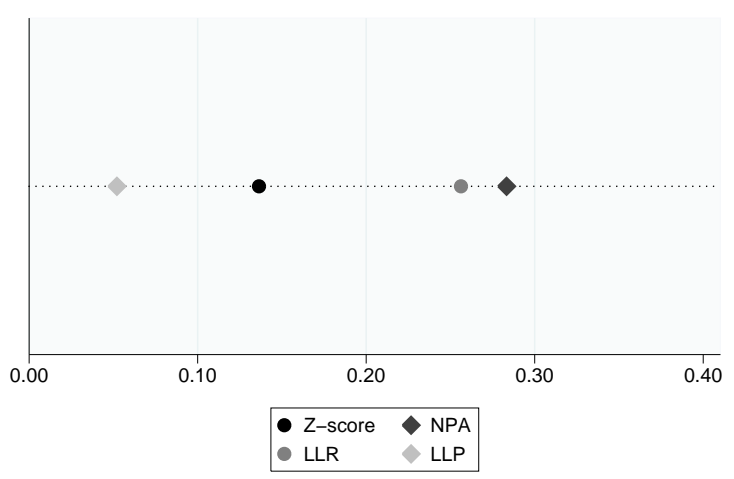

(a) Full period R-squared

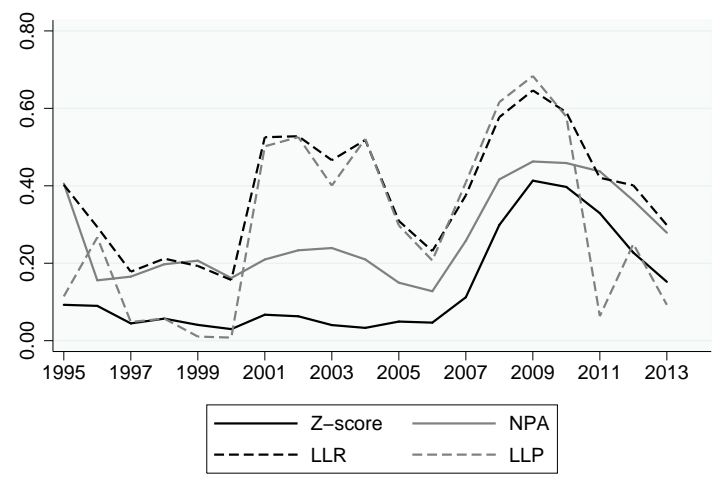

(b) Yearly R-squared

Table 2: Bank failures

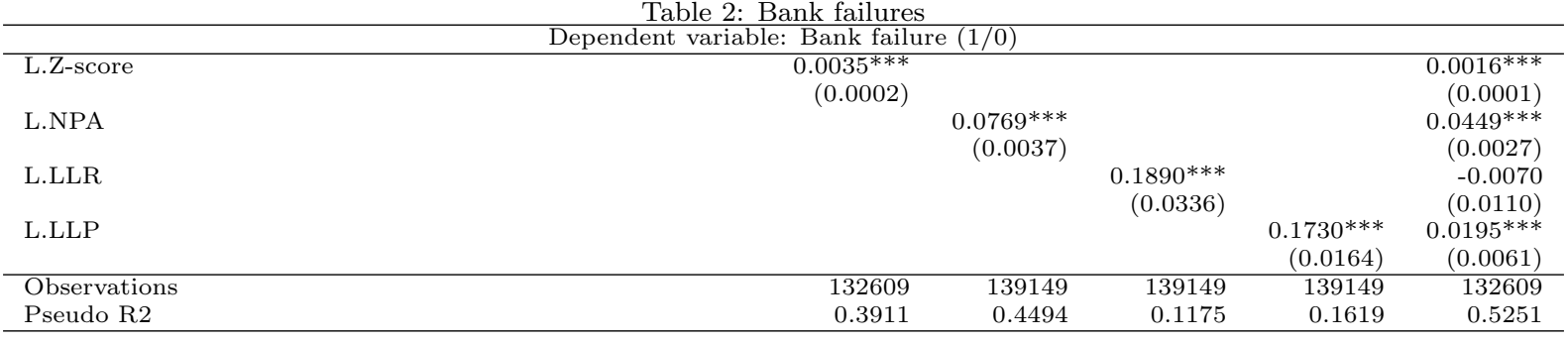

The dependent variable equals 1 if a bank failed. We report marginal effects of probit regressions. $*$, $* *$, $* *$ represents significance at the $10 \%, 5 \%, 1 \%$ level.

failure probability, respectively. The joint specification in column 5 shows that all four variables explain the variation in bank failures by around $52 \%$. While three variables remain significant, the economic impact is highest for the Z-score and NPA.

\section{Conclusion}

We investigate four proxies for bank risk that are frequently used in the literature. Our analysis shows that non-performing assets are a good proxy for bank risk for two reasons. First, non-performing assets nest the alternative proxies as shown by the high share of variation in non-performing assets explained by the Z-score, loan loss reserves and loan loss provisions. Second, non-performing assets are well-suited to explain bank failures one year ahead. The latter point also holds for the Z-score whereby the information content of the Z-score seems to differ from the other variables. We conclude that non-performing assets are a well-suited complement to the Z-score, which may come with calculation issues regarding the volatility of profitability, in studies of bank risk. 


\section{References}

Ahmed, A., Takeda, C., Thomas, S., 1999. Bank loan loss provisions: a reexamination of capital management, earnings management and signaling effects. Journal of Accounting and Economics 28, 1-25.

Anginer, D., Demirguc-Kunt, A., Zhu, M., 2013. How does deposit insurance affect bank risk? Evidence from the recent crisis. Journal of Banking \& Finance 48.

Anginer, D., Demirguc-Kunt, A., Zhu, M., 2014. How does competition affect bank systemic risk? Journal of Financial Intermediation 23, 1-26.

Barth, J. R., Caprio, G. J., Levine, R., 2004. Bank regulation and supervision: what works best? Journal of Financial Intermediation 13, 205-248.

Berger, A., Klapper, L., Turk-Ariss, R., 2009. Bank competition and financial stability. Journal of Financial Services Research 35, 99-118.

Carbo, S., Humphrey, D., Maudos, J., Molyneux, P., 2009. Cross-country comparisons of competition and pricing power in European banking. Journal of International Money and Finance 28, 115-134.

Cebenoyan, S. A., Strahan, P. E., 2004. Risk management, capital structure and lending at banks. Journal of Banking \& Finance 28, 19-43.

Cole, R. A., White, L. J., 2012. Déjà vu all over again: The causes of US commercial bank failures this time around. Journal of Financial Services Research 42, 5-29.

Dam, L., Koetter, M., 2012. Bank bailouts and moral hazard: Evidence from Germany. Review of Financial Studies 25, 2343-2380.

Elliott, J. A., Hanna, J. D., Shaw, W. H., 1991. The evaluation by the financial markets of changes in bank loan loss reserve levels. The Accounting Review 66, 847-861.

Gropp, R., Gruendl, C., Guettler, A., 2014. The impact of public guarantees on bank risk-taking: Evidence from a natural experiment. Review of Finance 18, 457-488.

Gropp, R., Hakenes, H., Schnabel, I., 2010. Competition, risk-shifting, and public bail-out policies. Review of Financial Studies, 2084-2120.

Hasan, I., Wall, L. D., 2004. Determinants of the loan loss allowance: Some cross-country comparisons. Financial Review 39, 129-152.

Jiménez, G., Lopez, J. A., Saurina Salas, J., 2013. How does competition impact bank risk-taking? Journal of Financial Stability 9, 185-195. 
Klomp, J., 2014. Financial fragility and natural disasters: An empirical analysis. Journal of Financial Stability 13, 180-192.

Laeven, L., Levine, R., 2009. Bank governance, regulation and risk taking. Journal of Financial Economics $93,259-275$.

Laeven, L., Majnoni, G., 2003. Loan loss provisioning and economic slowdowns: too much, too late? Journal of Financial Intermediation 12, 178-197.

Lepetit, L., Strobel, F., 2015. Bank insolvency risk and z-score measures: A refinement. Finance Research Letters http://dx.doi.org/10.1016/j.frl.2015.01.001.

Ng, J., Roychowdhury, S., 2014. Do loan loss reserves behave like capital? Evidence from recent bank failures. Review of Accounting Studies 19, 1234-1279.

Shaffer, S., 2012a. Bank failure risk: Different now? Economics Letters 116, 613-616.

Shaffer, S., 2012b. Reciprocal brokered deposits and bank risk. Economics Letters 117, 383-385.

Wheelock, D., Wilson, P., 2000. Why do banks disappear? The determinants of US bank failures and acquisitions. Review of Economics and Statistics 82, 127-138. 

